\title{
Self-Internet Infidelity and Partner Internet Infidelity. The Only Romanian Psychological Instruments Assessing the Online Extradyadic Behavior
}

\author{
Diana Filimon'1, Gheorghe Huza², Maria-Nicoleta Turliuc ${ }^{1}$ \\ ${ }^{1}$ Department of Psychology, Faculty of Psychology and Educational Sciences, Alexandru Ioan Cuza University, \\ Iași, Romania \\ ${ }^{2}$ Individual Psychology Office, Piatra Neamț, Romania \\ Email: diana_filimon_25@yahoo.com, george_huza60@yahoo.ro, turliuc@uaic.ro
}

How to cite this paper: Filimon, D., Huza, G., \& Turliuc, M.-N. (2021). Self-Internet Infidelity and Partner Internet Infidelity. The Only Romanian Psychological Instruments Assessing the Online Extradyadic Behavior. Open Journal of Social Sciences, 9, 120-140.

https://doi.org/10.4236/jss.2021.98010

Received: June 29, 2021

Accepted: August 6, 2021

Published: August 9, 2021

Copyright () 2021 by author(s) and Scientific Research Publishing Inc. This work is licensed under the Creative Commons Attribution International License (CC BY 4.0).

http://creativecommons.org/licenses/by/4.0/

\begin{abstract}
The aim of this study was to validate the Romanian version of the Internet Infidelity Scale (IIS), and to determine its psychometric properties in Romanian couple relationships. Specifically, IIS assesses the severity of 44 specific acts on both the Self Infidelity and the Partner Infidelity versions. Methods: 675 participants completed the Romanian version of the Internet Infidelity Scale (RVIIS), the Infidelity Scale (DIS), the Extra-Dyadic Behaviors Inventory (EBI), and the Satisfaction with Life Scale (SWLS). We used the exploratory (EFA) and confirmatory factor analysis (CFA) to examine the structure and models fit for Self and Partner Internet Infidelity. The scale's reliability, convergent and divergent validity were also tested. Results: The EFA and CFA analysis used for testing the matrix structure for Self and Partner Infidelity Scale revealed adequate models. An overall Cronbach's alpha of .80 for Self-Infidelity Scale and .88 for Partner Infidelity Scale, showed good internal consistency. Positive levels of convergent validity for each scale revealed that the instruments measure what they have intended to measure. The good fit of the scales ensures a pronounced robustness of the construct. Conclusions: The validated Romanian version of the Internet Infidelity Scale (RVIIS) is a valid and reliable instrument in rating the severity of 6 specific behaviors on both the Self-Infidelity and the Partner-Infidelity questionnaire. Given the limited number of research on people involved in couple relationships in Eastern Europe thus far, it is essential to provide validated tools to develop research in these countries.
\end{abstract}




\section{Keywords}

Internet Infidelity, Internet Infidelity Scale, Self-Infidelity, Partner Infidelity, Validity-Reliability

\section{Introduction}

Today, the Internet is clearly an essential component of our daily life, becoming one of the most exciting common places for social interaction and romance (Ben-Ze'ev, 2004). The advent of technological advancements and the magnetism of the virtual world allow people around the world to easily communicate. Millions of such users may be married, seriously dating, or cohabiting individuals, and they may use the Internet to meet strangers, flirt, and many times engage in highly sexualized conversations (Mileham, 2007). The large number of couples involved in extra-dyadic Internet relationships and online infidelity is a growing problem (Gerson, 2011; Nooripour et al., 2016). The difficulty of such relationships has led couples to seek help from counselors and therapists. Computer-mediated relationships are as important and significant as direct face-toface romantic and intimate relationships (Atwood, 2005; Cravens et al., 2013).

An online relationship is generally defined as any sexual or romantic relationship initiated via virtual communication and continues through other electronic communication such as email, or Internet conversations that occur in online communities such as chat rooms, interactive games, and news groups (Hertlein \& Piercy, 2012; Sharabi et al., 2021; Young et al., 2000). This online relationship becomes act of betrayal when an individual engages in secretive, romantic, or sexual behavior with a virtual partner, despite being engaged in a serious romantic relationship with someone in the "real" world (Norton et al., 2018; Young \& de Abreu, 2011). The findings of Abbasi and Dibble (2021) suggest that partners should be cautious when making friends online and should take proactive steps to avoid the possibility of engaging in infidelity behaviors. The technological sphere, including social media, cybersex, and written digital communication like email, text, and chat rooms, has been rapidly growing and it shows technology as an infidelity facilitator (Rothstein et al., 2021).

Theory of Planned Behavior (TPB) (Ajzen, 1985, 1991) is a very powerful and predictive cognitive model for explaining online infidelity. It evolved from the Theory of Reasoned Action (Fishbein \& Ajzen, 1975) which posited "intention to act" as the best-predictor of behavior. In addition to attitudes and subjective-norms, TPB adds the concept of perceived behavioral control, which originates from Self-Efficacy Theory (SET), proposed by Bandura in 1977. The premise of the TPB is that individuals make rational-decisions to engage in specific-behaviors based on their-own beliefs about the behaviors and their-expectation of a positive outcome after having engaged in the behaviors. TPB hypothesizes that infidelity happens because of the opportunity, as well as the intention 
to cheat. According to Ajzen (2002), an intention to perform a behavior is determined by three-components: 1) attitude toward a behavior (beliefs about a specific-behavior and its-consequences); 2) subjective-norm (normative-expectations of other-people who are important to the actor regarding the behavior), and 3) perceived-behavioral-control (the perceived-difficulty or ease of performing the behavior). Thus, the Internet infidelity takes on a special emphasis because partners are often subjective and self-serving and will take their needs into consideration rather than their partner's, thus justifying self-infidelity as more acceptable than partner-infidelity (Docan-Morgan \& Docan, 2007). Previous research has defined betrayal as either emotional and sexual, or online. But Internet infidelity can also include sexual and emotional infidelity (Cooper et al., 2003; Henline et al., 2007; Liu et al., 2020; Suliakaite, 2009).

Instruments for the investigation of the Internet infidelity phenomenon have been limited. Literature review suggests that among the tools used, the Internet Infidelity Scale of Docan-Morgan and Docan (2007) has high reliability and validity as an investigative research instrument and was found to be a valid and reliable measure in many foreign studies (Kallay, 2019). Based on Henline et al.'s (2007) study and the Internet Infidelity Questionnaire constructed by DocanMorgan and Docan (2007), Vossler and Moller (2020) focus on two themes which extend empirical understanding of the unique facets of internet as compared to face-to-face infidelity, particularly that participants perceived the online space to potentiate or encourage infidelity, in part because online behaviors and spaces create confusion about what "counts" as infidelity. On the other hand, to our knowledge, the single validation of this instrument is among the Internet users in Iran, in the study Exploring Validity and Reliability of Internet Infidelity Questionnaire among Internet Users in Iran (Nooripour et al., 2016). Furthermore, Suliakaite (2009) developed an Online Behavior Questionnaire that was primarily based on the Internet Infidelity Scale constructed by Docan-Morgan and Docan (2007), with the scope of exploring Lithuanians' attitudes and perceptions toward Internet infidelity and investigating whether interpersonal and intrapersonal factors were associated with the attitudes toward online affairs. The 44 specific acts of the Internet Infidelity Scale consider Internet infidelity behaviors such as: online chat, love, and sexualized conversations in an online environment, and exchange of personal information with other virtual users from the Internet space (Docan-Morgan \& Docan, 2007). Given the wide range of specific acts of internet infidelity, Docan-Morgan and Morgan (2007) found that identifying these behaviors was necessary to construct and develop a psychometric scale for their purposes. A few steps were made to establish validity. For the first time in an open-ended interview, the authors asked people to clearly state and define Internet activities that are considered unfaithful. The participants' responses yielded 294 specific actions and were examined for themes. Then, a total of six categories emerged, and each response was coded into one of the following categories: virtual sex, flirtatious behavior, emotional connection, seek- 
ing another (posting private videos or photos), conversing with another, exchanging personal information, and engaging in entertainment such as internet gaming with each other. These specific behaviors and themes aided in creating a list of 65 items or scenarios of possible infidelity.

In the next phase, the 65 -item questionnaire was given to researchers in the field of internet relationships to examine its validity. As many items of the master list were eliminated due to repetition, the total number of scenarios decreased from the initial list. The final version of the scale had 44 items, and asked participants to rate the severity from 1 (not infidelity) to 5 (highest degree of infidelity).

Factor analysis led to the extraction of two factors after conducting a sample of 208 participants. The first factor was superficial/informal acts such as talking about everyday subjects, sports, news, telling jokes and sending friendly emails to the virtual partner. The second factor was involving/goal-directed activities such as online emotional or sexual relationships with a virtual partner, flirting, expressing excessive intimacy to the Internet partner, and sending photos and personal videos.

In the Internet Infidelity Scale (IIS), the first version asked respondents to imagine that they were committing the acts and to express their attitude toward each of these actions, whereas the second version asked subjects to imagine their partners committing any one of these secret behaviors. Self-internet infidelity refers to personal acts of infidelity and highlights the self's perspective (e.g., Purtarea unei conversațiii online despre viața dvs. sexuală, cu o persoană intâlnită pe Internet/Having a conversation about your sex life in an Internet chat room with a person you met online), whereas partner internet infidelity refers to partner's acts of infidelity, also highlighting the self's approach (e.g., $O$ relație intimă, pe care partenerul/partenera dvs. o are cu o persoană întâlnită online/Your partner having an intimate relationship with a person he/she met on-line). Likewise, single participants were requested to complete the scale with an imaginary partner. The authors concluded that when the participants were rating goal driven or oriented acts, the ratings were more severe than if they were rating superficial or informal acts online (Connolly, 2018). On the other hand, Suliakaite (2009) showed that self-differentiation is associated with attitudes toward internet infidelity. Higher differentiated people considered less online behaviors to be unfaithful (Suliakaite, 2009), thus Lithuanians perceiving internet infidelity to be a multifaceted phenomenon. Nooripour et al. (2016) concluded that for most people having online extradyadic relationships, these are as real and as important as face-to-face-relationships. But because these findings are based on NorthCentral America and Northern Europe, it is an open question whether they can be generalized for Eastern Europe due to the differences in the contextual factors (socio-economic status, culture) (Rusu et al., 2015). Thus, the aim of this study was to adapt the Internet Infidelity Scale (IIS), determine its reliability and validity, and verify the adequacy of the Romanian adapted version of the six-dimensional scale. 


\section{Method}

\subsection{Research Design}

The study's procedure and the administered tools were fully compliant with the Declaration of Helsinki and with the University's Code of Ethics. To achieve the aim of this study, a cross-section correlational design type was used. Data collection was carried out by questionnaires through the main social networks as a method of recruitment, including on Facebook, Instagram, Twitter, Google+, and WhatsApp. This announcement directed participants to the online survey, where they read the informed consent, which reported the following: 1) the purpose of the study, 2) the inclusion criteria, 3) the voluntary nature of the study, 4) the possible risks, and 5) the right to withdraw from the study at any time. To protect the privacy of the participants, the questionnaires were completed anonymously (participants did not have to provide their name, phone number, or email).

\subsection{Participants}

A total of 675 participants (186 males, 489 females) with ages ranging from 23 73 (mean $=40.94 ; S D=11.09$ ) completed an online web-based survey. Some of the participants were recruited from different social media networks and some others from psychology and communication classes from two Romanian universities. Using the Internet to conduct quantitative research provided us the opportunity to transfer survey responses directly into an Excel database, eliminating transcription errors and preventing survey alteration by the survey respondent. Socio-demographic data included age, education level, marital status, relationship length. Sampling was based on convenience. Both versions were completed by participants after they were ensured that their participation in the study was anonymous and confidential. The purpose of the research was explained to every participant, and the data were completed on a voluntary basis. To participate in this study, we established the following inclusion criteria: being a resident of Romania, being 18 years of age or older, and having a heterosexual committed relationship (married or cohabitation).

\subsection{Measures}

\subsubsection{The Internet Infidelity Scale (IIS)}

The English version of the Internet Infidelity Scale (IIS) was translated into Romanian, and its validation process was performed through the forward-backward translation strategy and following the guidelines provided by the literature (Beaton et al., 2000; Dunn et al., 1994). The scale was developed by DocanMorgan and Docan (2007) to measure which types of acts involving the Internet are considered most severe, sex differences in the perception of infidelity, and the evaluation of infidelity when one commits it versus one's partner. The Romanian version of the scale was derived from the English version and was validated by the authors. The items were formulated using simple and appropriate 
language relative to the concept. However, according to previous literature on internet relationships, chat rooms are only one of the means for users to meet each other online, hence the term "chat room" in the Internet Infidelity Scale was changed to "online". For example, "having cybersex with a person you met in a chat room" was changed as follows: "having cybersex with a person you met online". Also, the ninth item: "having friendly conversations in a chat room titled "Married and Looking" was modified when translated into Romanian, as follows: "having friendly conversations online", due to the Romanian culture and reality.

Two 44-item versions of the scale were developed, the Self Infidelity (IISI) and the Partner Infidelity (IISP) Questionnaires. The first version asked participants to imagine that they were committing the acts, whereas the second version asked them to imagine that their partner was committing the behaviors. When rating the items, participants were asked to assume that they/their partner did not know that their partner/they were engaging in those behaviors. Respondents who did not have a partner were asked to rate the items as if they had a partner. Participants were also told to assume that the person they/their partner were interacting with online was someone to whom they/their partner could be romantically attracted (Docan-Morgan \& Docan, 2007). The severity of the rank scenario rated from $1=$ not infidelity; $2=$ slight degree; $3=$ considerable; $4=$ strong degree; 5 = highest degree. A score of 1 - 2 will indicate a low score of internet infidelity, a score of 3 is neutral, and a score of $4-5$ will indicate a high score of internet infidelity.

The first factor (15 items) - superficial/informal acts-accounted for $26.44 \%$ of the variance and the alpha reliability of these items was $\alpha=.95$. The second factor (12 items) -involving/goal-directed acts-accounted for $23.67 \%$ and its alpha reliability was $\alpha=.92$. For the present sample, the Cronbach's alpha for the IISI was .98 $($ mean $=2.30 ; S D=.90)$ and $.99($ mean $=2.51 ; S D=1.05)$ for the IISP.

\subsubsection{The Infidelity Scale (DIS, Drigotas et al., 1999)}

The Infidelity Scale, developed by Drigotas et al. (1999), consists of 11 items. Participants were asked to evaluate the level of attraction to a person, other than their partner, in either a current or past relationship on a 9-point Likert scale (0-not at all attractive; 8-extremely attractive). The items assessed both emotional and physical intimacy. In addition to using the emotional and physical intimacy scores, previous research by Drigotas et al., (1999) performed factor analysis, which revealed that nine of the 11 items loaded highest on a single factor that they labeled "composite infidelity". The 2 items that did not seem to relate to this factor were questions 2 and 6, which measured the speculation of how much the other person was attracted to the participant and initiation of the mutual attraction. However, because the other 9 items loaded so strongly on composite infidelity (factor loadings ranging from .61 to .85) the 9 items were averaged to form a composite infidelity score, with the maximum score being 
eight. For the present sample, the Cronbach's alpha for DIS was 96 (mean $=$ 7.36; $S D=3.74)$.

\subsubsection{Extra-Dyadic Behaviors Inventory (EBI; Luo et al., 2010)}

Extra-dyadic Behaviors Inventory (EBI; Luo et al., 2010) consists of 23 items assessing face-to-face EDB (e.g., "kissing"; "romantic date"; "received oral sex"; "vaginal intercourse") and 13 items assessing online EDB (including internet and phone interactions, e.g., "spent time online with romantic interest"; "shared sexually provocative pictures"; "phone sex"). Participants were asked to report how often they had engaged in each of the listed behaviors while in their current relationship with someone (of the opposite sex) other than their current partner. The instructions of the EBI were not phrased specifying that these behaviors are infidelity. In this inventory, Wiederman and Hurd's (1999) five-point rating scale was adopted by Luo et al. (p. 159): " 1 = Did not participate in this behavior because you didn't want to; $2=$ Did not participate in this behavior because there was no opportunity; 3 = Have participated in this behavior only once; $4=$ Have participated in this behavior more than once with the same person; and 5 = Have participated in this behavior with different people". In this study, we used the two-factor structure of the online EBI, namely: online sexual EBI and online emotional EBI. Cronbach's alpha was .92 (mean $=1.97 ; S D=1.01)$.

\subsubsection{Satisfaction with Life Scale (SWLS; Diener et al., 1985)}

A 7-point Likert style response scale (ranging from $1=$ strongly disagree to $7=$ strongly agree) was used to afford respondents an array of response options. The possible range of scores is therefore 5 to 35 , with a score of 20 representing the neutral point on the scale. Scores between 5 and 9 indicate that the respondent is extremely dissatisfied with life, whereas scores ranging between 31 and 35 indicate that the respondent is extremely satisfied with life. Scores between 21 and 25 represent slightly satisfied, and scores from 15 to 19 are interpreted as falling in the slightly dissatisfied range. For the present sample, the Cronbach's alpha for SWLS was .92 (mean $=26.30 ; S D=6.35)$.

\subsection{Statistical Analysis}

We used exploratory (EFA) and confirmatory factor analysis (CFA) with SPSS v. 20 to examine the matrix structure and the fit of the IISI and IISP. We chose 1) the absolute match measures (CMIN/DF) that determined the degree to which the model predicted the observed correlation matrix and whose value was recommended to be below 5, as well as the RMSEA that indicated approximate fits of the pattern in population. We also chose 2) the incremental measures (TLI, $\mathrm{CFI}$ ) that compared the proposed model to a baseline model that all other models should overtake and that indicated the discrepancy between the two models (Huza, 2019; Nokelainen, 2009). A scale has good reliability if when different occasions, under different conditions, and administered by different people, the measurements are repeatable (Drost, 2011; Huza, 2019). On a scale ranging be- 
tween 0 and 1, an internal consistency index of over .7 ensures good reliability. Validity refers to the quality of an instrument to measure what it has intended to measure (Huza, 2019; Kimberlin \& Winterstein, 2008). Convergent validity was examined with Spearman correlation calculations between the scores of the RVIIS and the scores of DIS and EBI. Divergent validity was examined with Spearman correlation calculations between the scores of the RVIIS and the scores of SWLS. A Wilcoxon test and Mann-Whitney test were conducted to evaluate the possible difference between variables.

\subsection{Results}

\subsubsection{Sample Characteristics}

Table 1 depicts the socio-demographic characteristics of the participants in the study.

\subsubsection{Exploratory Analysis}

The first step was to test the structure matrix of the two factors proposed by the authors of the 44 items scale. The EFA revealed appropriate indicators: the adequacy measure of sampling KMO (.829), Bartlett's test of sphericity $\left(\chi^{2}=26168\right.$; $p=.00)$. The two components accounted $68.83 \%$ of the variance. Testing the fit of model with CFA, we found that this model is inappropriate for Romanian people $(T L I=.55 ; C F I=.59 ; R M S E A=.222)$. The second step was to find a new matrix structure for Self and Partner Scale. We ran the EFA analysis, and we found appropriate models. The new models keep the two factors (Table 2 and Table 3).

Table 1. The socio-demographic characteristics of the participants.

\begin{tabular}{|c|c|}
\hline Characteristics & Mean $( \pm)$ or $n \%$ \\
\hline Age & $40.94(11.09)$ \\
\hline \multicolumn{2}{|l|}{ Gender } \\
\hline Male & $186(27.6)$ \\
\hline Female & $489(72.4)$ \\
\hline \multicolumn{2}{|l|}{ Residential environment } \\
\hline Village & $151(22.4)$ \\
\hline City & $524(77.6)$ \\
\hline \multicolumn{2}{|l|}{ Level of education } \\
\hline Pre-university & $336(49.8)$ \\
\hline University & $297(44.0)$ \\
\hline Post-university & $42(6.2)$ \\
\hline \multicolumn{2}{|l|}{ Marital status } \\
\hline Married & $492(72.9)$ \\
\hline Free union & $183(27.1)$ \\
\hline Relationship length & $16.6(8.01)$ \\
\hline
\end{tabular}


Table 2. Factor analysis of self scale.

\begin{tabular}{lcl}
\hline Item & Factor & \multicolumn{1}{c}{2} \\
\cline { 2 - 2 } & 1 &. \\
IISI22. Joking around with a person you met on-line in an Internet chat room. & .897 & .871 \\
IISI41. Joking around on Instant Messenger with a person you met on-line. & .835 \\
IISI19. Sending a friendly e-mail to someone you met on-line). & .876 \\
IISI17. E-mailing secrets that you do not tell your partner to a person you met on-line. & .875 \\
IISI20. Using Instant Messenger to tell a person you met on-line that you care for them. & .768 \\
IISI3. Having a conversation about your sex life in an Internet chat room with a person you met on-line. &. \\
\hline
\end{tabular}

Table 3. Factor analysis of partner scale.

\begin{tabular}{lc}
\hline Item & Factor \\
\hline IISP29. Your partner having an intimate relationship with a person he/she met on-line. & 1 \\
IISP32.Your partner posting his/her own personal ad on the Internet seeking other partners. & .966 \\
IISP5. Your partner telling a person that he/she met in a chat room that he/she loves them while chatting online. & .951 \\
IISP19. Your partner sending a friendly e-mail to someone he/she met on-line. & .950 \\
IISP11.Your partner sending e-mails to a person he/she met on-line. & .887 \\
IISP41. Your partner joking around on Instant Messenger with a person he/she met on-line. & .885 \\
\hline
\end{tabular}

\subsubsection{Condition for EFA Running for the Self and Partner Scales} The KMO test (.746) and Bartlett's test of sphericity $\left(\chi^{2}=1926.2 ; p=.00\right)$, revealed appropriate indicators for running the analysis. A rotated analysis with varimax rotation was conducted with two components, accounting for $76.00 \%$ of variance. Each factor was composed of three items and accounted $52.51 \%$ of the variance (the first) and $23.49 \%$ (the second).

The KMO test (.756) and Bartlett's test of sphericity $\left(\chi^{2}=4806.94 ; p=.00\right)$, revealed appropriate indicators for running the analysis. A rotated analysis with varimax rotation was conducted with two components, accounting for $90.34 \%$ of variance. Each factor was composed of three items and accounted $63.27 \%$ of the variance (the first) and $27.07 \%$ (the second).

\subsubsection{Confirmatory Analysis of the Scale}

For testing the fit of the Romanian Version of the Internet Infidelity Scale for Self and Partner, we conducted a confirmatory analysis with Amos 20.0. The results revealed a good fit of the structural models. Table 4 depicts the CFA results analysis. The models are shown in Figure 1.

In Figure 1, RVIISS represents the theoretical model for Self-Scale and RVIISP represents the theoretical model for Partner Scale. Both models have two factors: superficial/informal acts and involving/goal-directed acts. The RVIISS scale structure is revealed in Table 2 and the RVIISP scale structure is revealed in Table 3. 
RVIISS

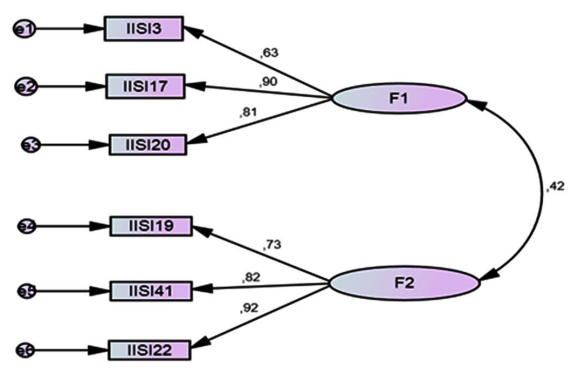

RVIISP

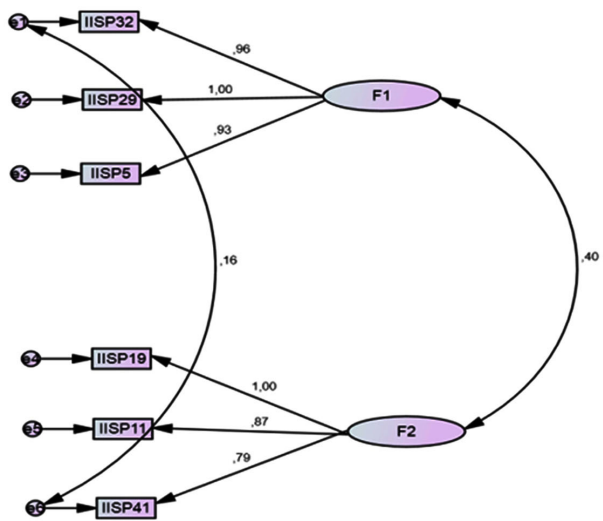

Figure 1. The theoretical models of the Romanian Version of the Internet Infidelity Scale (RVIIS).

Table 4. The CFA results.

\begin{tabular}{cccccc}
\hline Model & CMIN/DF & $p$ & RMSEA & TLI & CFI \\
\hline RVIISS & 3.982 & .000 & $.067[.043 ; .091]$ & .977 & .988 \\
RVIISP & 4.467 & .000 & $.072[.047 ; .098]$ & .989 & .995 \\
\hline
\end{tabular}

Note: RVIISS-Romanian Version of the Internet Infidelity Scale for Self. RVIISP-Romanian Version of the Internet Infidelity Scale for Partner.

\subsubsection{Reliability and Validity}

The reliability analysis revealed a good Cronbach's alpha of .80 for the Self-Scale. The corrected item to total correlation was greater than .3 (see Table 5). Both factors have high reliability values: .86 for the first factor (superficial/informal acts, SIA) and .82 for the second factor (involving/goal-directed acts, SDA).

The reliability analysis revealed a good Cronbach's alpha of .88 for the Partner Scale. The corrected item to total correlation was greater than .3 (see Table 6). Both factors have high reliability values: .91 for the first factor (superficial/ informal acts, PIA) and .97 for the second factor (involving/goal-directed acts, PDA).

Convergent validity for Self-Scale was supported by a significant correlation $\left(.47^{* *}\right)$ between the RVIISS total score and the DIS total score, respectively $\left(.43^{* *}\right)$ between the RVIISS total score and the EBI total score. Convergent validity is shown in Table 7.

Divergent validity was supported by a significant correlation between the RVIISS total score and SWLS total score. Divergent validity is shown in Table 8.

Convergent validity for the Partner Scale was supported by a significant correlation $\left(.46^{* *}\right)$ between the RVIISP total score and the DIS total score, respectively $\left(.42^{* *}\right)$ between the RVIISP total score and the EBI total score. Convergent validity is shown in Table 9 .

Divergent validity was supported by a significant correlation between the RVIISP total score and SWLS total score. Divergent validity is shown in Table 10 . 
Table 5. The 6 items for Self-Scale.

\begin{tabular}{|c|c|c|}
\hline \multirow{2}{*}{ Items } & \multicolumn{2}{|c|}{ Corrected Item-Total Cronbach's Alpha } \\
\hline & Correlation & if Item Deleted \\
\hline $\begin{array}{l}\text { IISI3. Purtarea unei conversații online despre viața dvs. sexuală, cu o persoană întâlnită pe internet. } \\
\text { (Having a conversation about your sex life in an Internet chat room with a person you met online). }\end{array}$ & .554 & .769 \\
\hline IISI17. Trimiterea unor email-uri referitoare la secrete, pe care nu le discutați cu partenerul/a dvs., cătr & & \\
\hline o persoană întâlnită online. & .692 & .732 \\
\hline (E-mailing secrets that you do not tell your partner to a person you met on-line). & & \\
\hline $\begin{array}{l}\text { IISI19. Trimiterea unui email prietenos unei persoane cunoscute online. } \\
\text { (Sending a friendly e-mail to someone you met on-line). }\end{array}$ & .480 & .785 \\
\hline $\begin{array}{l}\text { IISI20.Utilizarea Instant Messenger-ului pentru a declara unei persoane întâlnite online că țineți la ea. } \\
\text { (Using Instant Messenger to tell a person you met on-line that you care for them). }\end{array}$ & 623 & .753 \\
\hline $\begin{array}{l}\text { IISI22. Glumirea, online, cu o persoană întâlnită pe internet. } \\
\text { (Joking around with a person you met on-line in an Internet chat room). }\end{array}$ & .570 & .771 \\
\hline $\begin{array}{l}\text { IISI41. Glumirea, pe Instant Messenger, cu o persoană întâlnită online. } \\
\text { (Joking around on Instant Messenger with a person you met on-line). }\end{array}$ & .527 & .780 \\
\hline
\end{tabular}

Total Alpha $=.80$.

Table 6. The 6 items for Partner Scale.

\begin{tabular}{|c|c|c|}
\hline Items & $\begin{array}{l}\text { Corrected Item-Total } \\
\text { Correlation }\end{array}$ & $\begin{array}{l}\text { Cronbach's Alpha } \\
\text { if Item Deleted }\end{array}$ \\
\hline $\begin{array}{l}\text { IISP5. Mărturisirea sentimentelor de iubire pe care partenerul/partenera dvs. le are față de o persoan } \\
\text { intâlnită pe internet, în timpul unor discuții online. } \\
\text { (Your partner telling a person that he/she met in a chat room that he/she loves them while chatting } \\
\text { online). }\end{array}$ & .788 & .842 \\
\hline $\begin{array}{l}\text { IISP11. Trimiterea de email-uri, de către partenerul/partenera dvs., unei persoane întâlnite online. } \\
\text { (Your partner sending e-mails to a person he/she met on-line). }\end{array}$ & .606 & .873 \\
\hline $\begin{array}{l}\text { IISP19. Trimiterea unui email prietenos, de către partenerul/partenera } d v s \text {., unei persoane întâlnite } \\
\text { online. } \\
\text { (Your partner sending a friendly e-mail to someone he/she met on-line). }\end{array}$ & .626 & .871 \\
\hline $\begin{array}{l}\text { IISP29. O relație intimă, pe care partenerul/partenera dvs. o are cu o persoană întâlnită online. } \\
\text { (Your partner having an intimate relationship with a person he/she met on-line). }\end{array}$ & .830 & .834 \\
\hline $\begin{array}{l}\text { IISP32. Postarea unui anunț personal pe Internet, de către partenerul/partenera dvs., prin care } \\
\text { acesta/aceasta caută alți parteneri. } \\
\text { (Your partner posting his/her own personal ad on the Internet seeking other partners). }\end{array}$ & .826 & .834 \\
\hline $\begin{array}{l}\text { IISP41. Glumirea, de către partenerul/partenera dvs., pe Instant Messenger, cu o persoană întâlnită } \\
\text { online. }\end{array}$ & .509 & .885 \\
\hline
\end{tabular}

Total Alpha $=.88$.

Table 7. Convergent validity for Self-Scale.

\begin{tabular}{clll}
\hline Factor & DIS & EBI & $.43^{* *}$ \\
\hline RVIISS & $.47^{* *}$ & $.29^{* *}$ & $.40^{* *}$ \\
SIA & $.39^{* *}$ & $.39^{* *}$ & $.40^{*}$ \\
SDA & Sct
\end{tabular}

Note: RVIISS' total score-Romanian Version of the Internet Infidelity Scale; SIA-total score of the superficial/informal acts; SDA-total score of the involving/goal-directed acts; DIS-The Infidelity Scale; EBI-The Extra-Dyadic Behaviors Inventory; ${ }^{* *} p<.000$. 
Table 8. Divergent validity

\begin{tabular}{cc}
\hline Factor & SWLS \\
\hline RVIISS & $-.32^{* *}$ \\
SIA & $-.23^{* *}$ \\
SDA & $-.30^{* *}$ \\
\hline
\end{tabular}

Note: RVIISS-total score of the Romanian Version of the Internet Infidelity Self Scale; SIA-total score of the superficial/informal acts; SDA-total score of the involving/goal-directed acts; SWLS-The Satisfaction with Life Scale; ${ }^{* *} p<.000$.

Table 9. Convergent validity for Partner Scale.

\begin{tabular}{cll}
\hline Factor & DIS & EBI \\
\hline RVIISP & $.46^{* *}$ & $.42^{* *}$ \\
PIA & $.50^{\star *}$ & $.27^{* *}$ \\
PDA & $.30^{* *}$ & $.37^{* *}$ \\
\hline
\end{tabular}

Note: RVIISP-total score of Romanian Version of the Internet Infidelity Scale for Partner; PIA-total score of the superficial/informal acts; PDA-total score of the involving/goal-directed acts; DIS-The Infidelity Scale; EBI-The Extra-Dyadic Behaviors Inventory; ${ }^{* *} p<.000$.

Table 10. Divergent validity.

\begin{tabular}{cc}
\hline Factor & SWLS \\
\hline RVIISP & $-.22^{* *}$ \\
PIA & $-.22^{* *}$ \\
PDA & $-.26^{* *}$ \\
\hline
\end{tabular}

Note: RVIISP-total score of the Romanian Version of the Internet Infidelity Scale for Partner; PIA-total score of the superficial/informal acts; PDA-total score of the involving/goal-directed acts; SWLS-The Satisfaction with Life Scale; ${ }^{*} p<.000$.

Our findings confirm Docan-Morgan \& Docan's (2007) results that assume that informal/superficial acts are considered less severe than involving/goal-directed acts. We tested this assumption by Wilcoxon test for Self and Partner Scale. The results are the following: $z=-16.07, p=.00$, Mean rank $_{S I A}=129.85$, Mean $\operatorname{rank}_{S D A}=327.97$ for Self-Scale and: $z=-17.96, p=.00$, Mean $\operatorname{rank}_{P I A}=57.50$, Mean $\operatorname{rank}_{P D A}=282.02$ for the Partner Scale.

The second assumption assumes that partner's infidelity will be seen as more severe than self-infidelity will. Our results confirm this assumption: $z=-17.93$, $p=.00$, Mean rank $k_{\text {VIISS }}=103.37$, Mean rank $_{\text {RVIIS }}=311.72$. For all analyses, the highest values (sum of ranks) correspond to the positive ranks, which means that the ranks of the variables: SDA, PDA, RVIISP are higher than the ranks of the variables: SIA, PIA, RVIISS. Table 11 depicts how men and women perceive self-infidelity and partner's infidelity.

For all the analyses, the highest values (sum of ranks) correspond to the positive ranks, which means that the ranks of the variables: PIA, PDA, are higher than the ranks of the variables: SIA, SDA.

To find out whether the two scales discriminate according to age and relationship length, we divided the participants into age categories and different relationship lengths. Table 12 and Table 13 depict the results. 
Table 11. Wilcoxon test results for men and women ( $z$; Mean rank).

\begin{tabular}{ccccccc}
\hline & SIA & PIA & $\mathrm{z}$ & SDA & PDA & $\mathrm{z}$ \\
\hline Married men & 32.75 & 42.46 & $-4.61^{* *}$ & 10.50 & 55.49 & $-8.57^{* *}$ \\
Men in free union & 10.25 & 13.63 & $-2.00^{*}$ & 3.00 & 19.43 & $-4.90^{* *}$ \\
Married women & 94.70 & 118.64 & $-4.91^{* *}$ & 40.50 & 146.22 & $-13.58^{* *}$ \\
Women in free union & 27.54 & 36.15 & $-5.03^{* *}$ & 8.50 & 45.62 & $-7.84^{* *}$ \\
\hline
\end{tabular}

Note: SIA - total score of SIA; PIA - total score of PIA; SDA - total score of SDA; PDA-total score of PDA; ${ }^{*} p<.00 ;{ }^{*} p<.05$.

Table 12. Wilcoxon test results for men's age and women's age (z; Mean rank).

\begin{tabular}{cccccccc}
\hline & & SIA & PIA & $\mathrm{z}$ & SDA & PDA & $\mathrm{z}$ \\
\hline \multirow{2}{*}{ Men's age } & $31-50$ & 27.61 & 36.35 & $-4.08^{* *}$ & 10.00 & 48.46 & $-7.90^{* *}$ \\
& $>50$ & 5.21 & 10.44 & -1.35 & 2.50 & 11.41 & $-3.54^{* *}$ \\
\hline \multirow{2}{*}{$\begin{array}{c}\text { Women's } \\
\text { age }\end{array}$} & $31-50$ & 73.53 & 100.36 & $-5.97^{* *}$ & 31.50 & 119.60 & $-12.02^{* *}$ \\
& $>50$ & 11.50 & 22.93 & -1.09 & 8.50 & 23.17 & $-5.62^{* *}$ \\
\hline
\end{tabular}

Note: SIA - total score of SIA; PIA - total score of PIA; SDA — total score of SDA; PDA-total score of PDA; ${ }^{* *} p<.00$.

Table 13. Wilcoxon test results for men's relationship length and women's relationship length ( $\mathrm{z}$; Mean rank).

\begin{tabular}{cccccccc}
\hline & & SIA & PIA & $\mathrm{z}$ & SDA & PDA & $\mathrm{z}$ \\
\hline $\begin{array}{c}\text { Men's } \\
\text { relationship } \\
\text { length }\end{array}$ & $5-15$ & 18.80 & 24.62 & $-5.05^{* *}$ & 6.50 & 33.28 & $-6.80^{* *}$ \\
\hline $\begin{array}{c}\text { Women's } \\
\text { relationship }\end{array}$ & $5-15$ & 18.30 & 19.48 & -1.19 & 4.00 & 19.81 & $-4.93^{* *}$ \\
\hline length & $>5$ & 15.88 & 24.02 & $-3.13^{* *}$ & 4.00 & 43.44 & $-7.97^{* *}$ \\
\hline
\end{tabular}

Note: SIA - total score of SIA; PIA-total score of PIA; SDA-total score of SDA; PDA-total score of PDA; ${ }^{* *} p<.00$.

For all the analyses the highest values (sum of ranks) correspond to the positive ranks, which means that the ranks of the variables: PIA, PDA, are higher than the ranks of the variables: SIA, SDA.

Docan-Morgan \& Docan (2007) proposed the hypothesis that women will rate acts of Internet infidelity as more severe than men will rate acts of Internet infidelity. Our study confirms the hypothesis for men and women with age less than 30 years, but only for self-involving/goal-directed acts ( $U=1433.00 ; z=-2.09, p$ $=.037$; Mean rank $_{M E N}=59.65 ;$ Mean rank $\left.{ }_{W o m e n}=76.47\right)$. The severity for each item of the Romanian version scales is shown in Table 14. 
Table 14. Acts of Infidelity.

\begin{tabular}{|c|c|c|c|c|c|c|c|}
\hline & \multicolumn{2}{|c|}{ Self-Infidelity } & \multicolumn{5}{|c|}{ Partner infidelity } \\
\hline & Mean & $\mathrm{SD}$ & Mean & $\mathrm{SD}$ & $\mathrm{t}$ & $\mathrm{df}$ & $p$ \\
\hline $\begin{array}{l}\text { Having an online conversation about your sex life with a } \\
\text { person you met on the Internet/Your partner having an } \\
\text { intimate relationship with a person he/she met online. }\end{array}$ & 2.25 & 1.28 & 3.56 & 1.73 & -25.11 & 674 & .00 \\
\hline $\begin{array}{l}\text { E-mailing secrets that you do not tell your partner to a } \\
\text { person you met online/ Your partner posting his/her own } \\
\text { personal ad on the Internet seeking other partners. }\end{array}$ & 2.58 & 1.45 & 3.29 & 1.62 & -17.65 & 674 & .00 \\
\hline $\begin{array}{l}\text { Using Instant Messenger to tell a person you met online } \\
\text { that you care for them/ Your partner telling a person that } \\
\text { he/she met online that he/she loves them while chatting on } \\
\text { the Internet. }\end{array}$ & 2.78 & 1.43 & 3.31 & 1.63 & -14.47 & 674 & .00 \\
\hline $\begin{array}{l}\text { Sending a friendly e-mail to someone you met online/Your } \\
\text { partner sending a friendly e-mail to someone he/she met } \\
\text { online. }\end{array}$ & 1.69 & .81 & 1.91 & 1.07 & -7.09 & 674 & .00 \\
\hline $\begin{array}{l}\text { Joking around with a person you met online on the } \\
\text { Internet/Your partner sending e-mails to a person he/she } \\
\text { met online. }\end{array}$ & 1.78 & .81 & 2.02 & 1.13 & -6.25 & 674 & .00 \\
\hline $\begin{array}{l}\text { Joking around on Instant Messenger with a person you met } \\
\text { online/Your partner joking around on Instant Messenger } \\
\text { with a person he/she met online. }\end{array}$ & 1.58 & .75 & 1.80 & 1.00 & -8.70 & 674 & .00 \\
\hline
\end{tabular}

The EFA of the Self and Partner Scales show appropriate models. The 6 items of Self Scale (RVIISS) show a good Cronbach's alpha of .80. Both its factors have high reliability values: .86 for the first factor (superficial/informal acts, SIA) and .82 for the second factor (involving/goal-directed acts, SDA). The 6 items of Partner Scale (RVIISP) show also a good Cronbach's alpha of .88. Both its factors have high reliability values: .91 for the first factor (superficial/informal acts, PIA) and .97 for the second factor (involving/goal-directed acts, PDA). A significant correlation between the RVIIS for Self and Partner with DIS and EBI has indicated a good convergent validity. (.47**, respectively $.43^{* *}$ for Self-Scale and $.46^{* \star}$, respectively $.42^{\star *}$ for Partner Scale). From the items of the original scales, the Romanian version of the two scales preserves only those items (6) that ensure a pronounced robustness of the construct. The CFA confirms this robustness through the high values of indicators: RMSEA $=.067$ [.043; .091]; TLI $=.977 ; \mathrm{CFI}=.988$ for Self-Scale and RMSEA $=.072[.047 ; .098]$; TLI $=.988, \mathrm{CFI}$ $=.995$ for Partner Scale. It shows that the models are appropriate and do not falsify the reality. The high psychometric qualities of the Romanian version of the Internet Infidelity Scale (RVIIS) for Self and Partner recommend it for both screening and research. The two versions of the Internet Infidelity Scale (the Self-Scale and the Partner Scale), along with the behavior's description and the rank scenario, are depicted in Appendix.

\section{Discussions and Conclusion}

\subsection{Discussions}

The aim of the present study was to test the psychometric properties of the Ro- 
manian version of the Internet Infidelity Scale for Self and Partner in a sample of different social categories on Romanian people. To our knowledge, this scale has not been used in Romania before. As already mentioned, the IIS (Docan-Morgan \& Docan, 2007) measures which types of acts involving the Internet are considered the most severe type of online infidelity, sex differences in the perception of infidelity, and the evaluation of infidelity when one commits it versus one's partner. Translation into Romanian and cross-cultural adaptation of the English version was done without high difficulties, using forward-backward translation strategy. The items were formulated using simple and appropriate language relative to the concept. No participant reported issues in reading and understanding the IIS items. The psychometric properties showed that the Romanian version of IIS is a valid and reliable tool to assess the internet infidelity in Romanian samples.

The results of the assessment of the internal consistency were good. In their study, Docan-Morgan \& Docan (2007) found a good reliability for the Internet Infidelity Questionnaire (.92 - .95 for subscales). Our study showed good Cronbach's alpha of .8 (.86 - .82 for subscales) for the Self Scale, and .88 (.91 - .97 for subscales) for the Partner Scale. The Romanian Version of the Internet Infidelity Scale for Self and for Partner maintains the two factors of the original version. If the original version keeps the same items for self and partner (e.g., Joking around on Instant Messenger with a person you met on-line; Your partner joking around on Instant Messenger with a person he/she met on-line), the Romanian version contains both common and specific items (see Table 5 and Table 6). It shows us that we judge our partner's infidelity in qualitative terms as well (e.g., Having a conversation about your sex life in an Internet chat room with a person you met on-line versus Your partner having an intimate relationship with a person he/she met on-line). The Romanian version of the Internet Infidelity Scale is related to gender, marital status, age categories and relationship length, and it discriminates between informal/superficial acts and involving/ goal-directed acts. As a rule, both men and women regardless of marital status, evaluate the partner's infidelity as more severe than their own (both superficial/informal acts and the involving/goal-directed acts). Our results agree with the findings of other authors (Abdi et al., 2012; Docan-Morgan \& Docan, 2007; Shrout \& Weigel, 2020; Vossler \& Moller, 2020). Age can be a factor in influencing the judgment of infidelity. Our findings show that men and women over 50 years old have similar judgments about infidelity only in terms of superficial/informal acts. Regarding the relationship length, only men under the age of 30 and those over the age of 50 evaluate their own informal/superficial acts and those of their partner's with the same severity. These results are in accordance with Whitty (2003) that highlights age differences and relationship status in attitudes towards sexual infidelity. The hypothesis that younger people rate acts of internet infidelity as more severe than older individuals is in accordance with Whitty (2003) that assumes that younger people were more likely to rate sexual acts as acts of betrayal than older individuals. Our scale indicates that women evaluate infidelity more severe than men. That is in accordance with Moreno, 
and Kahumoku-Fessler's (2018) results that show that females rated sexual and emotional behaviors higher than males.

\subsection{Strengths and Limitations}

There are strengths in the design and methodological approach of our study (e.g., the sample size, EFA, CFA, divergent and convergent validity) which increase our confidence in the results. Nevertheless, the current study comprises several limitations including the use of self-report measures, the lack of random sampling, and of test-retest reliability. The convenience sample used in this study that does not use the random sampling suggested that future research should analyze the factor structure of questionnaires in populations with different characteristics. Also, the study had low sample variability since subjects belonged to six specific geographical areas of the country. To validate the predictive capacity of the scale, it is necessary for future studies to analyze scale predictability with respect to other factors (e.g., intention and behavior; pornography consumption and online sexual activities). Lastly, future research should include longitudinal research, evaluate the test-retest reliability and predictive validity of the IIS.

\subsection{Conclusion}

The Romanian version of the Internet Infidelity Scale for Self and Partner showed a high reliability and a good convergent validity. The good fit of the two scales recommends its use in detecting internet infidelity. The high psychometric qualities of the Romanian Version of RVIIS Scales recommend it for various studies. To confirm the robust psychometric characteristics of the RVIIS, future studies should include homogenous populations as well (e.g., only adolescents, only adults, only married people). The RVIIS scales can detect the online extradyadic behaviors and help many people seek specialized help to reconsider and strengthen the couple and family relationships.

\section{Acknowledgements}

This paper and the research behind it would not have been possible without the exceptional support of Diana Filimon's supervisor, Maria-Nicoleta Turliuc. Her enthusiasm, knowledge and exacting attention to detail have been an inspiration and kept her work on track from her first encounter with the challenging topic of online infidelity to the final draft of this paper. She is also grateful for the insightful comments offered by her friend and colleague, Gheorghe Huza, who was involved in the interpretation of data and statistical analysis. The authors thank the anonymous referees for their useful suggestions.

\section{Authors' Contributions}

Diana Filimon: Conceptualization of study's design, Literature review, Data acquisition and interpretation, Methodology, Formal analysis, Writing: original 
draft.

Gheorghe Huza: Conceptualization of study's design, Literature review, Interpretation of data and statistical analysis, Writing: original draft.

Maria-Nicoleta Turliuc: Conceptualization, Methodology, Writing: review \& editing, Supervision.

\section{Conflicts of Interest}

The authors declare no conflicts of interest regarding the publication of this paper.

\section{References}

Abbasi, I. S., \& Dibble, J. L. (2021). The Role of Online Infidelity Behaviors in the Link between Mental Illness and Social Media Intrusion. Social Science Computer Review, 39, 70-83. https://doi.org/10.1177/0894439319857079

Abdi, M., Nazari, A., Mohseni, M., \& Zabihzadeh, A. (2012). Internet Infidelity: Exploration of Attitudes towards Partners Internet Behaviors. Zahedan Journal of Research in Medical Sciences, 14, 72-75.

Ajzen, I. (1985). From Intentions to Actions: A Theory of Planned Behavior. In J. Kuhl, \& J. Beckmann (Eds), Action Control: From Cognition to Behavior (pp. 11-39). Springer. https://doi.org/10.1007/978-3-642-69746-3 2

Ajzen, I. (1991). Theory of Planned Behavior. Organization Behavior and Human Decision Process, 50, 179-211. https://doi.org/10.1016/0749-5978(91)90020-T

Ajzen, I. (2002). Attitudes, Personality, and Behavior. Open University Press.

Atwood, J. D. (2005). Cyber-Affairs: "What's the Big Deal?”. Therapeutic Considerations. Journal of Couple \& Relationship Therapy, 4, 117-134. https://doi.org/10.1300/J398v04n02 11

Beaton, D. E., Claire, B., Francis, G., \& Marcos, B. F. (2000). Guidelines for the Process of Cross-Cultural Adaptation of Self-Report Measures. Spine, 25, 3186-3191. https://doi.org/10.1097/00007632-200012150-00014

Ben-Ze'ev, A. (2004). Love Online: Emotions on the Internet. Cambridge University Press. https://doi.org/10.1017/CBO9780511489785

Connolly, M. (2018). A Study into the Difference in Relationship Satisfaction between People Who Met Their Partners Online versus People Who Met in Person. Undergraduate Thesis, National College of Ireland. http://norma.ncirl.ie/id/eprint/3287

Cooper, A., Månsson, S.-A., Daneback, K., Tikkanen, R., \& Ross, M. (2003). Predicting the Future of Internet Sex: Online Sexual Activities in Sweden. Sexual and Relationship Therapy, 18, 277-291. https://doi.org/10.1080/1468199031000153919

Cravens, J. D., Leckie, K. R., \& Whiting, J. B. (2013). Facebook Infidelity: When Poking Becomes Problematic. Contemporary Family Therapy, 35, 74-90. https://doi.org/10.1007/s10591-012-9231-5

Diener, E., Emmons, R. A., Larsen, R. J., \& Griffin, S. (1985). The Satisfaction with Life Scale. Journal of Personality Assessment, 49, 71-75. https://doi.org/10.1207/s15327752jpa4901 13

Docan-Morgan, T., \& Docan, C. A. (2007). Internet Infidelity: Double Standards and the Differing Views of Women and Men. Communication Quarterly, 55, 317-342. https://doi.org/10.1080/01463370701492519

Drigotas, S. M., Safstrom, C. A., \& Gentilia, T. (1999). An Investment Model Prediction 
of Dating Infidelity. Journal of Personality \& Social Psychology, 77, 509-524. https://doi.org/10.1037/0022-3514.77.3.509

Drost, E. A. (2011). Validity and Reliability in Social Science Research. Education Research and Perspectives, 38, 105.

Dunn, S. C., Rbert, F. S., \& Mattew, A. W. (1994). Latent Variables in Business Logistics Research: Scale Development and Validation. Journal of Business Logistics, 15, 145.

Fishbein, M., \& Ajzen, I. (1975). Belief, Attitude, Intention and Behavior: An Introduction to Theory and Research. Addison-Wesley.

Gerson, M.-J. (2011). Cyberspace Betrayal: Attachment in an Era of Virtual Connection. Journal of Family Psychotherapy, 22, 148-156. https://doi.org/10.1080/08975353.2011.578039

Henline, B. H., Lamke, L. K., \& Howard, M. D. (2007). Exploring Perceptions of Online Infidelity. Personal Relationships, 14, 113-128. https://doi.org/10.1111/j.1475-6811.2006.00144.x

Hertlein, K. M., \& Piercy, F. P. (2012). Essential Elements of Internet Infidelity Treatment. Journal of Marital and Family Therapy, 38, 257-270. https://doi.org/10.1111/j.1752-0606.2011.00275.x

Huza, G. (2019). The Psychometric Properties of a Romanian Version of the Centrality of Religiosity Scale (CRS 15). Religions, 10, 11. https://doi.org/10.3390/rel10010011

Kallay, R. H. (2019). Perceptions of Online Cheating: Impact of Age, Gender, and Sexual Preference. Walden Dissertations and Doctoral Studies Collection, Walden University.

Kimberlin, C. L., \& Winterstein, A. G. (2008). Validity and Reliability of Measurement Instruments Used in Research. American Journal of Health-System Pharmacy, 65, 2276-2284. https://doi.org/10.2146/ajhp070364

Liu, Y., Yue, C., \& Zheng, L. (2020). Influence of Online Sexual Activity (OSA) Perceptions on OSA Experiences among Individuals in Committed Relationships: Perceived Risk and Perceived Infidelity. Sexual and Relationship Therapy, 35, 162-177. https://doi.org/10.1080/14681994.2019.1636957

Luo, S., Cartun, M. A., \& Snider, A. G. (2010). Assessing Extradyadic Behavior: A Review, a New Measure, and Two New Models. Personality and Individual Differences, 49, 155-163. https://doi.org/10.1016/j.paid.2010.03.033

Mileham, B. L. A. (2007). Online Infidelity in Internet Chat Rooms: An Ethnographic Exploration. Computers in Human Behavior, 23, 11-31. https://doi.org/10.1016/j.chb.2004.03.033

Moreno, N., \& Kahumoku-Fessler, E. P. (2018). Understanding Infidelity: How Perceptions of Infidelity Behaviors Vary by Sex and One's Own Infidelity Experiences. The American Journal of Family Therapy, 46, 107-121. https://doi.org/10.1080/01926187.2018.1441760

Nokelainen, P. (2009). Structural Equation Modeling with AMOS. University of Tampere.

Nooripour, R., Abdi, M. R., Bakhshani, S., Alikhani, M., Hosseinian, S., \& Pour Ebrahim, T. (2016). Exploring Validity and Reliability of Internet Infidelity Questionnaire among Internet Users in Iran. International Journal of High-Risk Behaviors and Addiction, 6, Article ID: e34928. https://doi.org/10.5812/ijhrba.34928

Norton, A. M., Baptist, J., \& Hogan, B. (2018). Computer-Mediated Communication in Intimate Relationships: Associations of Boundary Crossing, Intrusion, Relationship Satisfaction, and Partner Responsiveness. Journal of Marital and Family Therapy, 44, 165182. https://doi.org/10.1111/jmft.12246

Rothstein, N. J., Connolly, D. H., de Visser, E. J., \& Phillips, E. (2021). Perceptions of In- 
fidelity with Sex Robots. In Proceedings of the 2021 ACM/IEEE International Conference on Human-Robot Interaction (pp. 129-139). APA. https://doi.org/10.1145/3434073.3444653

Rusu, P. P., Hilpert, P., Beach, S. R. H., Turliuc, M. N., \& Bodenmann, G. (2015). Dyadic Coping Mediates the Association of Sanctification with Marital Satisfaction and WellBeing. Journal of Family Psychology, 29, 843-849. https://doi.org/10.1037/fam0000108

Sharabi, L. L., Uhlich, M., Alexopoulos, C., \& Timmermans, E. (2021). Exploring Links between Online Infidelity, Mate Poaching Intentions, and the Likelihood of Meeting Offline. Cyberpsychology, Behavior, and Social Networking, 24, 450-456. https://doi.org/10.1089/cyber.2020.0563

Shrout, M. R., \& Weigel, D. J. (2020). Coping with Infidelity: The Moderating Role of Self-Esteem. Personality and Individual Differences, 154, Article ID: 109631. https://doi.org/10.1016/j.paid.2019.109631

Suliakaite, A. (2009) Lithuanians' Attitudes toward Internet Infidelity and Its Correlates. Texas Woman's University.

Vossler, A., \& Moller, N. P. (2020). Internet Affairs: Partners' Perceptions and Experiences of Internet Infidelity. Journal of Sex \& Marital Therapy, 46, 67-77. https://doi.org/10.1080/0092623X.2019.1654577

Whitty, M. T. (2003). Pushing the Wrong Buttons: Men's and Women's Attitudes toward Online and Offline Infidelity. Cyberpsychology \& Behavior, 6, 569-579. https://doi.org/10.1089/109493103322725342

Young, K. S., \& de Abreu, C. N. (2011). Internet Addiction: A Handbook and Guide to Evaluation and Treatment. John Wiley \& Sons, Inc. https://doi.org/10.1002/9781118013991

Young, K. S., Griffin-Shelley, E., Cooper, A., O’Mara, J., \& Buchanan, J. (2000). Online Infidelity: A New Dimension in Couple Relationships with Implications for Evaluation and Treatment. Sexual Addiction \& Compulsivity, 7, 59-74.

https://doi.org/10.1080/10720160008400207 


\section{Appendix}

Internet Infidelity Scale-Self Infidelity Version (Scala Infidelităţii pe Internet. Versiunea: Auto Infidelitate (adică propriile dvs. acțiuni)

\section{Comportament:}

Presupuneți că partenerul/a dvs. NU ŞTIE că vă angajați în acest tip de comportament.

Presupuneți că persoana cu care interacționați online este cineva de care ați putea fi atras(ă) în mod romantic.

În cele ce urmează, veți întâlni 6 comportamente pe Internet. Vă rog să bifați varianta corespunzătoare alegerii dvs. din opțiunile de mai jos, astfel: 1) non-infidelitate; 2) un anumit grad;3) considerabil; 4) grad ridicat; 5) cel mai înalt grad.

Behavior:

Assume that your partner DOES NOT KNOW you are engaging in these behaviors.

Assume that the person you are interacting with online is someone to whom you could be romantically attracted.

Rank scenario how severe 1 - 5: $1=$ not infidelity; $2=$ slight degree; $3=$ considerable; $4=$ strong degree; $5=$ highest degree.

1) Purtarea unei conversații online despre viața dvs. sexuală, cu o persoană întâlnită pe Internet.

(Having a conversation about your sex life in an Internet chat room with a person you met online.)

2) Trimiterea unor e-mail-uri referitoare la secrete, pe care nu le discutaţi cu partenerul/a dvs., către o persoană întâlnită online.

(E-mailing secrets that you do not tell your partner to a person you met online.)

3) Trimiterea unui e-mail prietenos unei persoane cunoscute online.

(Sending a friendly e-mail to someone you met on-line.)

4) Utilizarea Instant Messenger-ului pentru a declara unei persoane întâlnite online că țineți la ea.

(Using Instant Messenger to tell a person you met on-line that you care for them.)

5) Glumirea, online, cu o persoană întâlnită pe Internet.

(Joking around with a person you met on-line in an Internet chat room.)

6) Glumirea, pe Instant Messenger, cu o persoană întâlnită online.

(Joking around on Instant Messenger with a person you met on-line.)

Internet Infidelity Scale-Partner's Infidelity Version (Scala Infidelităţii pe Internet. Versiunea: Infidelitatea partenerului/partenerei (adică acţiunile partenerului/partenerei dvs.)

\section{Comportament:}

Presupuneți că NU ŞTIȚI că partenerul/partenera dvs. se angajează în acest tip de comportament. În cazul în care nu aveți un partener/o parteneră, răspun- 
deți ca şi cum ați avea.

Presupuneți că persoana cu care partenerul/partenera dvs.interacționează online este cineva de care partenerul/partenera dvs. ar putea fi atras(ă) în mod romantic.

În cele ce urmează, veți întâlni 6 comportamente pe Internet. Vă rog să bifați varianta corespunzătoare alegerii dvs. din opțiunile de mai jos, astfel: 1 -non-infidelitate; 2-un anumit grad; 3-considerabil; 4-grad ridicat; 5-cel mai înalt grad.

\section{Behavior:}

Assume that you DO NOT KNOW that your partner is engaging in these behaviors when the occur. If you do not have a partner, respond as if you do.

Assume that the person your partner is interacting with online is someone to whom your partner could be romantically attracted.

Rank scenario how severe 1 - 5: 1 = not infidelity; 2 = slight degree; 3 = considerable; 4 = strong degree; 5 = highest degree.

1) Mărturisirea sentimentelor de iubire pe care partenerul/partenera dvs. le are față de o persoană întâlnită pe Internet, în timpul unor discuții online.

(Your partner telling a person that he/she met in a chat room that he/she loves them while chatting online.)

2) Trimiterea de email-uri, de către partenerul/partenera dvs., unei persoane întâlnite online.

(Your partner sending e-mails to a person he/she met on-line.)

3) Trimiterea unui e-mail prietenos, de către partenerul/partenera dvs., unei persoane întâlnite online.

(Your partner sending a friendly e-mail to someone he/she met on-line.)

4) O relație intimă, pe care partenerul/partenera dvs. o are cu o persoană întâlnită online.

(Your partner having an intimate relationship with a person he/she met on-line.)

5) Postarea unui anunț personal pe Internet, de către partenerul/partenera dvs., prin care acesta/aceasta caută alți parteneri.

(Your partner posting his/her own personal ad on the Internet seeking other partners.)

6) Glumirea, de către partenerul/partenera dvs., pe Instant Messenger, cu o persoană întâlnită online.

(Your partner joking around on Instant Messenger with a person he/she met on-line.)

Note: Participants were asked to assume that they/their partner did not know that they/their partner was engaging in these behaviors. They were also told to assume that the person they/their partner was interacting with online was someone to whom they/their partner could be romantically attracted. Questions were phrased in accordance with self-infidelity (e.g., "Trimiterea unor e-mail-uri referitoare la secrete, pe care nu le discutați cu partenerul/a dvs., către o persoană întâlnită online.”), and partner infidelity (e.g., "Postarea unui anunț personal pe Internet, de către partenerul/partenera dvs., prin care acesta/aceasta caută alți parteneri."). 